\section{Gastric mucosal calcinosis}

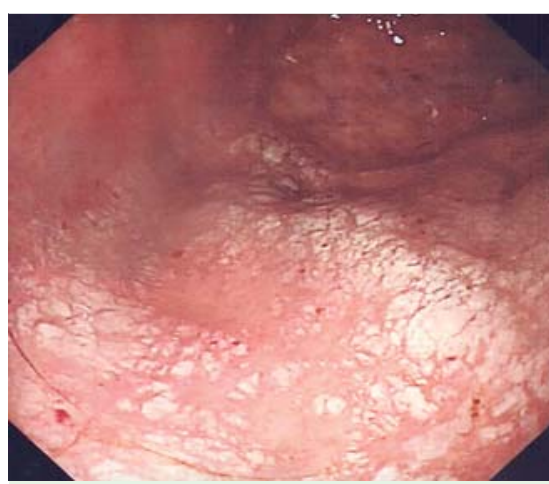

Fig. 1 Endoscopic appearance in a 68-year-old woman with end-stage kidney disease showing varying numbers of 1-3-mm, white, flat lesions in the gastric body.

A 68-year-old woman with end-stage kidney disease due to hypertension presented with nausea, vomiting, dyspepsia, and epigastric pain. Endoscopy revealed varying numbers of 1 -3-mm diameter, white, flat plaques in the gastric body ( Fig. 1). Laboratory results included the following (normal ranges are given in brackets): blood urea $86.2 \mathrm{mg} / \mathrm{dL}(6.0-21.0 \mathrm{mg} / \mathrm{dL})$; creatinine $\quad 4.2 \mathrm{mg} / \mathrm{dL} \quad(0.6-1.1 \mathrm{mg} / \mathrm{dL})$; calcium $9.2 \mathrm{mg} / \mathrm{dL}(8.9-10.1 \mathrm{mg} / \mathrm{dL})$, corrected calcium $10.08 \mathrm{mg} / \mathrm{dL}$; phosphorus $8.7 \mathrm{mg} / \mathrm{dL}(2.5-4.5 \mathrm{mg} / \mathrm{dL})$; and albumin $2.9 \mathrm{~g} / \mathrm{dL}(3.5-5.0 \mathrm{mg} / \mathrm{dL})$. Urinalysis showed proteinuria $(+++)$. The calcium-phosphate product was $87.6 \mathrm{mmol} / \mathrm{L}$ (normal $<60$ ) and plasma intact parathyroid hormone level was $121 \mathrm{pg} / \mathrm{mL}(9.5-75 \mathrm{pg} /$ $\mathrm{mL}$ ).

Histologic examination of gastric biopsies showed widespread deposits of subepithelial microcalcification in the superficial gastric mucosa. The deposits of microcalcification were irregular, amorphous and extended into the lamina propria. Calcium was colored as black pigment in the von Kossa stain ( Fig.2). Stains for cytomegalovirus, herpes, and iron were negative. Helicobacter pylori was also identified in the biopsy material.

Calcific deposits in the gastric mucosa are only rarely found in routine biopsies: metastatic calcification is the most common type of gastric mucosal calcinosis, with other underlying diseases being uremia and chronic renal disease. Hypercalcemia,

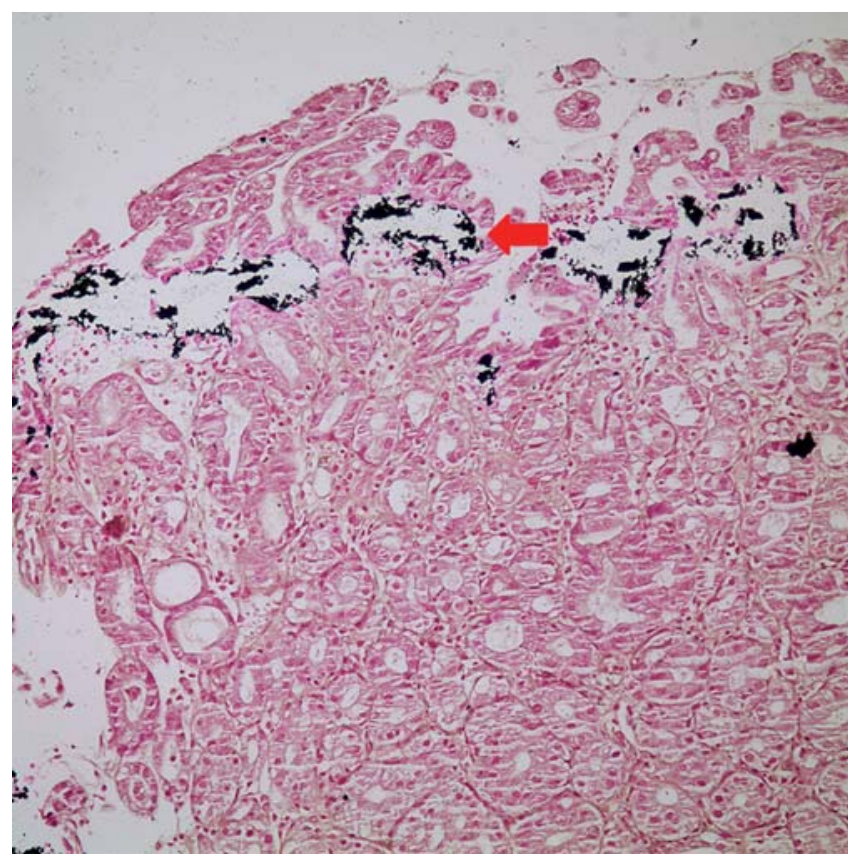

hyperphosphatemia, and an elevated calcium - phosphate product have been suggested as being the most important factors in the development of metastatic calcification [1-3]. H. pylori was positive in the present case; however, it is not significantly associated with gastric calcinosis. Although several drugs have been suspected of having a role in the etiology [4], there was no history of administration of alendronate, oral iron, aluminum-containing antacids, or sucralfate in our case.

Endoscopy_UCTN_Code_CCL_1AB_2AD_3AF

Competing interests: None

\section{B. Yılmaz ${ }^{1}$, S. Köklü ${ }^{1}$, C. Sökmensüjer ${ }^{2}$}

${ }^{1}$ Department of Gastroenterology, Hacettepe University School of Medicine, Ankara, Turkey

2 Department of Pathology, Hacettepe University School of Medicine, Ankara, Turkey

\section{References}

1 Parfitt AM. Soft tissue calcification in uremia. Arch Intern Med 1969; 124: 544-556

2 Kim TH, Yang SY. Stomach calcification revealed by gastrofibroscopy in a haemodialysis patient. Nephrology 2010; 15: 592 -593

3 Stroehlein KB, Stroehlein JR, Kahan BD et al. Gastric mucosal calcinosis in renal transplant patients. Transplant Proc 1999; 31: 2124-2126

4 Gorospe M, Fadare 0 . Gastric mucosal calcinosis clinicopathologic considerations. Adv Anat Pathol 2007; 14: 224-228

\section{Bibliography}

Dol http://dx.doi.org/ $10.1055 / \mathrm{s}-0033-1344590$

Endoscopy 2013; 45: E275

(c) Georg Thieme Verlag KG

Stuttgart · New York

ISSN 0013-726X

\section{Corresponding author}

\section{B. Yilmaz, MD}

Department of Gastroenterology

Hacettepe University School of Medicine

Ankara

Turkey

Fax: +90-312-3058487

bulent.yilmaz@hacettepe.edu.tr 